\title{
Gambaran Tumbuh Kembang Balita Stunting Umur 24-60 Bulan di Desa Pringgarata Wilayah Kerja UPT BLUD Puskesmas Pringgarata
}

\author{
Haris Suhamdani ${ }^{1)}$, L.Sadam Husen ${ }^{2)}$, Teguh Achmalona ${ }^{3)}$, Nining Fatria Ningsih ${ }^{4 *}$, Hasrun Ningsih ${ }^{5)}$ \\ Email: niningfatria@gmail.com \\ 1,2,3 Jurusan Keperawatan UNIQHBA Bagu Lombok Tengah \\ ${ }^{4,5}$ Jurusan Kebidanan UNIQHBA Bagu Lombok Tengah
}

\begin{abstract}
ABSTRAK
Stunting merupakan suatu kondisi gagal pertumbuhan pada anak (pertumbuhan tubuh dan otak) akibat kekurangan gizi dalam waktu yang lama. Status Gizi (PSG) 2018 menunjukkan prevalensi Balita stunting di Indonesia masih tinggi, yakni 30,8\% di atas batasan yang ditetapkan WHO (20\%). Mengetahui gambaran tumbuh kembang balita stunting di Desa Pringgarata wilayah kerja UPTD Puskesmas Pringgarata. Penelitian ini merupakan penelitian deskriptif dengan pendekatan kuantitatif. Populasi studi penelitian ini adalah semua balita stunting umur 24-60 bulan yang berada di Desa Pringgarata wilayah kerja Puskesmas Pringarata. Sampel berjumlah 93 orang balita. Tingkat pertumbuhan : berat badan kategori kurang 50 responden $(53,76 \%)$, tinggi badan kategori pendek 58 responden $(62,36 \%)$, lingkar kepala kategori sesuai 76 responden $(81,72 \%)$.Tingkat perkembangan kategori meragukan 51 responden $(54,83 \%)$. Ketidakcukupan asupan nutrisi yang berlangsung lama mulai dari semenjak masa kehamilan sampai usia 24 bulan menyebabkan tumbuh kembang anak menjadi terhambat.
\end{abstract}

Keywords : Balita, Tumbuh Kembang, Stunting

\begin{abstract}
Stunting is a condition of growth failure in children (body and brain growth) due to prolonged malnutrition. Nutritional Status (PSG) 2018 shows that the prevalence of stunting under five in Indonesia is still high, which is $30.8 \%$ above the limit set by WHO (20\%). To determine the description of the growth and development of children under five with stunting in the working area of the UPTDPringgarata public health. This research is a descriptive study with a quantitative approach. The study population of this study were all stunting infants aged 24-60 months who were in the working area of the Pringaratapublic health center. The sample was 93 toddlers. The growth rate: underweight category 50 respondents $(53.76 \%), 58$ respondents $(62.36 \%)$ short category height, 76 respondents $(81.72 \%)$ in the appropriate category. The level of development in the dubious category was 51 respondents (54.83\%). Insufficient nutritional intake that lasts for a long time starting from pregnancy to 24 months of age causes children's growth and development to be hampered.
\end{abstract}

Keywords: Toddler, Growth and Development, Stunting 


\section{A. LATAR BELAKANG}

Indonesia adalah Negara berkembang yang memiliki permasalahan yang kompleks terutama dalam masalah gizi. Gizi di Indonesia atau Negara berkembang lain memiliki kasus gizi yang berbeda dengan Negara maju, yaitu Indonesia memiliki masalah gizi ganda yang artinya status gizi yang menunjukkan keadaan disatu sisi daerah terdapat gizi kurang dan disisi lain terdapat gizi lebih. Masalah tersebut merupakan salah satu permasalahan yang menjadi focus pemerintah Indonesia sampai dengan saat ini. Jika hal tersebut tidak ditanggapi secara serius, maka akan meningkatkan resiko terjadinya angka kesakitan, kematian dan hambatan pada pertumbuhan motorik maupun mental [1].

Indonesia telah menunjukkan hasil persentase penurunan kemiskinan secara tetap, tetapi hal tersebut tidak di imbangi dengan penurunan permasalahan gizi pada anak-anak. Masalah gizi kurang tersebut yang berdampak buruk pada anak-anak menunjukkan hanya menunjukkan sedikit perbaikan. Dari tahun 2016 sampai 2020, proporsi penduduk miskin di Indonesia mengalami penurunan sebesar 16,612,5 persen, tetapi masalah gizi kurang tidak menunjukkan penurunan secara signifikan.

Gizi kurang menyebabkan prevalensi stunting (anak pendek) sangat tinggi. Prevalansi stunting balita di Indonesia berada diperingkat kedua tertinggi dikawasan Asia Tenggara dibawah Laos dengan 43,8\%. Berdasarkan Riset Kesehatan Dasar (Riskesdas) yang dilakukan oleh Badan Penelitian dan Pengembangan Kesehatan (Litbangkes) tentang prevalansi stunting di Indonesia. Berdasarkan penelitian tersebut angka stunting di Indonesia sebesar $30,8 \%$, angka tersebut jauh dari standar yang telah ditetapkan oleh WHO yaitu sebesar $20 \%$. [1]

Ada beberapa faktor yang dapat menjadi penyebab terjadinya stunting, yaitu status ekonomi keluarga, riwayat BBLR dan yang terpenting adalah pemenuhan asupan gizi yang mencukupi pada saat ibu hamil, kemudian pola asuh dan pemenuhan gizi yang cukup sampai anak berusia 23 bulan atau pemenuhan gizi pada masa 1000 hari pertama kehidupan sehingga dapat tumbuh dan berkembang secara optimal [2].

Hal tersebut sejalan dengan penelitian yang dilakukan oleh Lutifiana Oktadila pada tahun 2019 untuk mengetahui faktor-faktor yang berhubungan dengan kejadian stunting di wilayah kerja UPT Puskesmas Klecorejo Kabupaten Madiun. Hasil penelitian menunjukkan variabel pekerjaan di peroleh hasil $p$ value $=0,002$, pendapatan keluarga dengan $p$ value $=0,000$, riwayat BBLR dengan $p$ value $=$ 0,002 dan riwayat ASI ekslusif dengan $\mathrm{p}$ value $=$ 0,000 . Hasil tersebut menunjukan bahwa semua variabel yang diteliti merupakan faktor yang berhubungan dengan kejadian stunting di wilayah kerja UPT Puskesmas Klecorejo Kabupaten Madiun [3].

Berdasarkan hasil dari pencatatan elektronik pelaporan gizi masyarakat (e-PPGBM), angka prevalensi stunting di Provinsi NTB sendiri masih sangat tinggi yaitu sebesar 33,49\%. Kabupaten Lombok Timur merupakan daerah dengan persentasi tertinggi sebanyak $43 \%$ dan terendah Kabupaten Sumbawa barat dengan 18\% dari angka keseluruhan kasus yang ada di NTB. Sedangkan Angka Kejadian stunting di Lombok Tengah pada tahun 2020 terbilang masih cukup tinggi dari 65 ribu balita di Lombok Tengah sebanyak 32\% mengalami stunting [4].

Data yang didapatkan di UPT BLUD Puskesmas Pringgarata, kasus stunting mencapai (520 kasus) pada bulan September 2020. Pada desa Sepakek sebanyak (97 kasus), di Pemepek sebanyak (70 kasus), di Arjangka sebanyak (69 kasus), di Taman Indah sebanyak (100 kasus), di Murbaya sebanyak (59 kasus), dan di Pringgarata sebanyak 121 kasus [4][5].

Berdasarkan data tersebut diatas, membuat peneliti tertarik untuk melakukan penelitian dengan judul" Gambaran tumbuh kembang pada balita dengan stunting Di Desa Pringgarata Wilayah kerja UPT BLUD Puskesmas Pringgarata. 


\section{B. METODE PENELITIAN}

Jenis penelitian ini adalah deskriptif dengan pendekatan kuantitatif menggunakan metode observasi dan penilaian langsung terhadap obyek yang diteliti. Populasi yang diambil pada penelitian ini adalah 121 balita yang mengalami stunting berdasarkan data yang ada di Desa Pringgarata wilayah kerja UPTD Puskesmas Pringgarata. Pemilihan sampel pada penelitian ini menggunakan Simple random sampling sehingga diperoleh 93 sampel berdasarkan kriteria yang telah ditetapkan oleh peneliti.

Untuk memperoleh data mengenai pertumbuhan pada balita stunting didapatkan melalui pemeriksaan Berat Badan, Tinggi Badan dan Lingkar Kepala dengan menggunakan timbangan, metelin dan lembar catatan. Sedangkan untuk melakukan pengukuran tingkat perkembangan menggunakan lembar KPSP.

\section{HASIL DAN PEMBAHASAN}

\section{Distribusi karakteristik responden}

Tabel 1. Distribusi karakteristik responden berdasarkan jenis kelamin

\begin{tabular}{|c|c|c|c|}
\hline No & JK & Frekuensi & Persentase \\
\hline 1. & Laki-laki & 38 & 37,63 \\
\hline 2. & Perempuan & 27 & 62,37 \\
\hline
\end{tabular}

Berdasarkan tabel diatas dari 93 responden terdapat 58 responden $(62,37 \%)$ diantaranya berjenis kelamin laki-laki dan 35 responden $(37,63 \%)$ berjenis kelamin perempuan.

Tabel 2. Distribusi karakteristik responden berdasarkan umur

\begin{tabular}{lccc}
\hline No & Umur & Frekuensi & Persentase \\
\hline 1. & 24 bulan & 15 & 16,13 \\
\hline 2. & 30 bulan & 9 & 9,67 \\
\hline 3. & 42 bulan & 13 & 13,97 \\
\hline 4. & 48 bulan & 18 & 19,35 \\
\hline 5. & 54 bulan & 20 & 21,50 \\
\hline 6. & 60 bulan & 18 & 19,35 \\
\hline Total & & 93 & 100 \\
\hline
\end{tabular}

Berdasarkan tabel diatas dari 93 responden yang memiliki umur paling banyak adalah usia 54 bulan dengan 20 responden $(21,50 \%)$ dan paling sedikit sejumlah 9 responden $(9,67 \%)$ memiliki umur 30 bulan.
Tabel 3. Distribusi karakteristik responden berdasarkan berat badan

\begin{tabular}{llcc}
\hline No & BB & Frekuensi & Persentase \\
\hline 1. & Baik & 17 & 18,27 \\
\hline 2. & Cukup & 26 & 27,95 \\
\hline 3. & Kurang & 50 & 53,76 \\
\hline Total & & 93 & 100 \\
\hline
\end{tabular}

Berdasarkan tabel diatas dari 93 responden dapat disimpulkan bahwa berat badan responden dengan kategori kurang lebih tinggi yaitu sebanyak 50 responden $(53,76 \%)$, responden dengan kategori cukup mencapai 26 responden $(27,95 \%)$ dan kategori baik 17 responden $(18,27 \%)$.

Tabel 4. Distribusi karakteristik responden berdasarkan tinggi badan

\begin{tabular}{llcc}
\hline No & TB & Frekuensi & Persentase \\
\hline 1. & Pendek & 58 & 62,36 \\
\hline 2. & Sangat Pendek & 35 & 37,63 \\
\hline Total & & 93 & 100 \\
\hline
\end{tabular}

Berdasarkan tabel diatas dari 93 responden sebanyak 58 responden $(62,36 \%)$ sedangkan responden dengan tinggi badan sangat pendek sebanyak 35 responden $(37,63 \%)$.

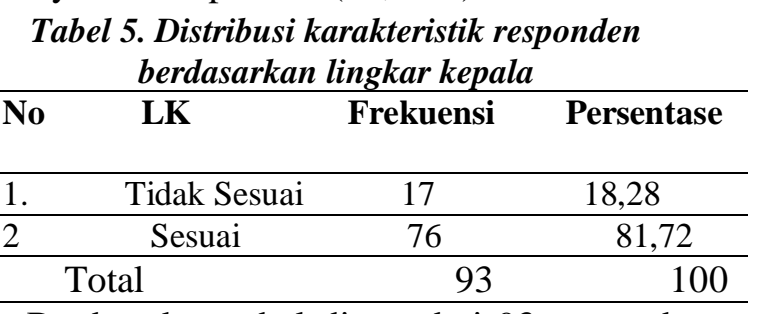

Berdasarkan tabel diatas dari 93 responden sejumlah 76 responden $(81,72 \%)$ memiliki lingkar kepala yang sesuai, sedangkan yang memiliki lingkar kepala yang tidak sesuai yaitu sejumlah 17 responden $(18,28 \%)$

Tabel 6. Distribusi karakteristik responden berdasarkan tingkat perkembangan

\begin{tabular}{llcc}
\hline No & TP & Frekuensi & Persentase \\
\hline 1. & Meragukan & 51 & 54,83 \\
\hline 2. & Sesuai & 27 & 29,03 \\
\hline 3. & Penyimpangan & 15 & 16,12 \\
\hline Total & & 93 & 100 \\
\hline
\end{tabular}

Berdasarkan tabel diatas dari 93 responden perkembangan pada balita stunting dengan kategori meragukan lebih tinggi yaitu sebanyak 51 responden $(54,83 \%)$ jika di bandingkan dengan kategori sesuai yaitu sebanyak 27 responden $(29,03 \%)$ dan kategori penyimpangan lebih rendah yaitu sebanyak 15 responden 
$(16,12 \%)$.

\section{Pertumbuhan Balita Stunting}

Menurut Keputusan dari Menkes RI No1995/MENKES/SK/XII/2010 tentang Standar Antropometri Penilaian Status Gizi Anak, pengertian pendek dan sangat pendek adalah status gizi yang didasarkan pada indeks Panjang Badan menurut Umur $(\mathrm{PB} / \mathrm{U})$ atau Tinggi Badan menurut Umur (TB/U) yang merupakan padanan istilah stunted (pendek) dan severely stunted (sangat pendek) [6]. Balita pendek (stunting) dapat diketahui bila seorang balita sudah diukur panjang atau tinggi badannya, lalu dibandingkan dengan standar, dan hasilnya berada di bawah normal [7].

Kegagalan pertumbuhan (growth faltering) pada balita stunting akibat dari akumulasi ketidakcukupan nutrisi yang berlangsung lama mulai dari semenjak masa kehamilan sampai usia 24 bulan. Keadaan ini diperparah dengan tidak terimbanginya atau tidak seimbangnya kejar tumbuh (catch up growth) yang memadai.

Ada beberapa faktor yang sering dikaitkan dengan masalah gangguan pertumbuhan pada balita stunting yaitu kemiskinan, sosial dan budaya, peningkatan paparan terhadap penyakit infeksi, kerawanan pangan dan akses masyarakat terhadap pelayanan kesehatan. Masalah pertumbuhan pada balita stunting dapat berpengaruh pada anak balitadalam jangka waktu yang panjang. Hal tersebut dapat mengganggu kesehatan, proses pendidikan serta produktifitasnya di kemudian hari. Anak balita stunting cenderung akan sulit mencapai potensi pertumbuhan dan perkembangan yang optimal baik secara fisik maupun psikomotorik [8].

Upaya intervensi meliputi perbaikan gizi dan kesehatan Ibu hamil merupakan cara terbaik dalam mengatasi stunting. Ibu hamil perlu mendapat makanan yang baik, sehingga apabila ibu hamil terhindar dari Kurang Energi Kronis (KEK). Kemudian persalinan ditolong oleh bidan atau dokter terlatih dan begitu bayi lahir melakukan Inisiasi Menyusui Dini (IMD). Bayi sebelum 6 bulan diberi ASI ekslusif dan bayi mulai usia 6 bulan sampai 2 tahun, selain ASI bayi diberi makanan pendamping ASI. Bayi dan anak juga harus memperoleh kapsul vitamin A,dan imunisasi dasar lengkap, serta melakukan pemantauan pertumbuhan balita di posyandu merupakan upaya yang sangat strategis untuk mendeteksi dini terjadinya gangguan pertumbuhan [9].

\section{Perkembangan Balita Stunting}

Perkembangan merupakan suatu proses bertambahnya kemampuan (skill) dalam struktur dan fungsi tubuh yang lebih kompleks dalam pola yang teratur dan dapat diramalkan sebagai hasil proses pematangan. Perkembangan menyangkut adanya proses diferensiasi sel-sel tubuh, jaringan tubuh, organ-organ, dan sistem organ yang berkembang sedemikian rupa sehingga masing-masing dapat memenuhi fungsi di dalamnya termasuk pula perkembangan emosi, intelektual, dan tingkah laku sebagai hasil interaksi dengan lingkungannya [10].

Keadaan kurang gizi yang yang lebih berat dan kronis tidak hanya mengganggu pertumbuhan (stunting), tetapi juga menyebabkan jumlah sel dalam otak berkurang dan terjadi ketidakmatangan serta ketidaksempurnaan organisasi biokimia dalam otak. Keadaan ini dapat berpengaruh terhadap perkembangan kecerdasan anak Kekurangan gizi pada masa lampau akan menyebabkan perubahan metabolisme di dalam otak terutama jika terjadi saat golden period ( 3 tahun) pertumbuhan dan perkembangan otak anak. Hal ini akan menyebabkan ketidakmampuan otak untuk berfungsi normal [11].

Perkembangan pada balita dapat dinilai dari tiga hal, yaitu secara fisik, kognitif, dan psikososial.Masalah stunting yang dimiliki anak memiliki dampak terhadap menurunnya intelektualitas dan kemampuan kognitif anak. Dalam Makalah Utama Bidang 5 Widyakarya Nasional Pangan dan Gizi XI 2018 oleh Lembaga Ilmu Pengetahuan Indonesia disebutkan bahwa stunting di awal kehidupan 
seorang anak dapat menyebabkan kerusakan permanen pada perkembangan kognitif, yang diikuti dengan perkembangan motorik dan intelektual yang kurang optimal sehingga cenderung dapat menimbulkan konsekuensi terhadap pendidikan, pendapatan, dan produktivitas pada masa dewasa sehingga berpotensi menurunkan pertumbuhan ekonomi [12].

Menurut Kementerian Kesehatan Republik Indonesia, anak yang menderita stunting memiliki risiko perkembangan kognitif, motorik, dan verbal yang kurang optimal dan dapat berdampak pada menurunnya kapasitas belajar dan prestasi belajar di sekolah. Menurunnya kapasitas belajar dan performa anak pada masa sekolah dapat mengakibatkan produktivitas dan kinerja saat anak dewasa juga menjadi tidak optimal. Hal ini merupakan dasar penanggulangan stunting harus menjadi prioritas untuk kemajuan sumber daya manusia Indonesia [13].

\section{KESIMPULAN}

Ketidakcukupan asupan nutrisi yang berlangsung lama mulai dari semenjak masa kehamilan sampai usia 24 bulan merupakan penyebab terjadinya stunting pada balita. Hal tersebut ditandai dengan adanya suatu ketidaksesuaian antara umur dengan tingkat pertumbuhan dan perkembangan yang dimiliki anak.

\section{DAFTAR PUSTAKA}

[1] Balitbangkes. 2018. Riset Kesehatan Dasar 2018.Kemenkes.Jakarta : 252-253.

[2] Nurillah. 2018. Faktor Risiko Kejadian Stunting pada Balita Usia24-36 bulan di kecamatan Semarang Timur. Journal Of Nutriton College.

[3] Lutfiana Oktadila. 2019. Faktor Resiko Kejadian Stunted pada Anak Usia 7-24 Bulan Di Puskesmas Klecorejo Kabupaten Madiun.FIK UMS. Surakarta

[4] Dinkes prov NTB.Rencana Aksi Nasional Pangan dan Gizi 2020. Badan Perencanaan Pembangunan Nasional (BAPPENAS)
[5] Puskesmas Pringgarata. 2020. Profil kesehatan Puskesmas Pringgarata. lombok tengah

[6] Kemenkes, 2010.Peraturan Menteri Kesehatan Republik Indonesia Nomor : 1995/MENKES/SK/XII/2010 tentang Standar Antropometri Penilaian Status Gizi Anak. Direktorat Bina Gizi dan Kesehatan Ibu dan Anak.

[7] Kemenkes RI. 2012. Buku Kesehatan Ibu dan Anak.Kementerian Kesehatan dan JICA. Jakarta.

[8] Aridiyah et at. 2015. Faktor-faktor yang Mempengaruhi Kejadian Stunting pada Anak Balita di Wilayah Pedesaan dan Perkotaan (The Factors Affecting Stunting on Toddlers in Rural and Urban Areas. eJurnal Pustaka Kesehatan. 3(1). 163-170.

[9] Lidia. 2018. Hubungan BBLR dan asi eksklusif dengan kejadian stunting di Puskesmas Lima Puluh Pekanbaru. Jurnal Endurance 3(1).131-137.

[10] Suparisa. 2016. Menilai Status Gizi untuk Mencapai Sehat Optimal. Leutika.Yogyakarta.

[11] Khomsan N. 2012. Social Competence of 3 to 5-year-old Children Born with Low Birth Weight.Journal Paediatrica Indonesiana. 2012;49(2):97-103.

[12] LIPI. 2018. Validasi Klinik Strenghts and Difficulties Questionnaire (SDQ) sebagai Instrumen Skrining Gangguan Tingkah Laku.

[13] Kementerian Kesehatan Republik Indonesia. Infodatin Situasi Balita Pendek. Jakarta; 2016. 